\title{
Proses dan Kendala Pembelajaran Biologi di Masa Pandemi Covid-19: Analisis Respon Mahasiswa
}

\author{
${ }^{1 *}$ Ita Ainun Jariyah, ${ }^{1}$ Esti Tyastirin \\ ${ }^{1}$ Program Studi Biologi UIN Sunan Ampel Surabaya, Jawa Timur. Jl. Jend. A. Yani 117 Surabaya \\ 60237, Indonesia. Telp. (031) 8410298, Fax. (031) 8413300
}

${ }^{*}$ Corresponding Author e-mail: itaainunjariyah@gmail.com

Received: June 2020; Revised: June 2020; Published: July 2020

\begin{abstract}
Abstrak
Program studi Biologi UIN Sunan Ampel Surabaya telah memberlakukan pembelajaran daring pada Semester Genap Tahun Akademik 2019/2020 sebagai upaya memastikan perkuliahan tetap berjalan di masa pandemi COVID-19. Penelitian ini bertujuan untuk menganalisis proses dan kendala pembelajaran biologi di masa pandemi COVID-19 berdasarkan respon mahasiswa Jenis Penelitian ini adalah deskriptif kualitatif, Pengambilan data dilakukan dengan membagikan Google form yang berisi 11 pertayaan kepada 82 orang mahasiswa angakatan 2017, 2018, dan 2019. Hasil penelitian ini menunjukkan bahwa proses perkuliahan daring di Prodi Biologi UIN Sunan Ampel Surabaya berjalan cukup baik. Beberapa kendala diantaranya banyak menghabiskan kuota serta jaringan internet lemah. Proses perkuliahan masih perlu untuk terus dioptimalkan dan perlu untuk dilakukan evaluasi demi perbaikan perkuliahan daring pada periode berikutnya.
\end{abstract}

Kata Kunci: Perkuliahan daring, Pandemi COVID-19, respon mahasiswa

\section{The Biology Learning Processes and Constraints in the Covid-19 Pandemic Period: Analysis of Student Responses}

\section{Abstract}

The Biology Study Program of UIN Sunan Ampel Surabaya has implemented online learning in the Even Semester, Academic Year 2019/2020 as an effort to ensure lectures continue during the COVID-19 pandemic. This study aimed to analyze the processes and constraints of biology learning in the COVID-19 pandemic based on student responses. This research type was qualitative descriptive, data collection was done by distributing Google form containing 11 questions to 82 students 2017, 2018, and 2019. The results of this study indicate that the online lecture process at Biology Study Program of UIN Sunan Ampel Surabaya was going pretty well. Some obstacles include spending a lot of quota and a weak internet network. The lecture process still needs to be continuously optimized and evaluation needs to be done to improve online lectures in the next period.

Keywords: Online lectures, COVID-19 Pandemic, student responses

How to Cite: Jariyah, I., \& Tyastirin, E. (2020). Proses dan Kendala Pembelajaran Biologi di Masa Pandemi Covid-19: Analisis Respon Mahasiswa. Jurnal Penelitian dan Pengkajian Ilmu Pendidikan: eSaintika, 4(2), 183-196. doi:https:// doi.org/10.36312/e-saintika.v4i2.224

\section{PENDAHULUAN}

Coronavirus Disease 2019 (COVID-19) yang disebakan oleh SARS-CoV-2 saat ini tengah menjadi pandemi (Cucinotta \& Vanelli, 2020; Hsu, Chia, \& Vasoo, 2020; LloydSherlock et al., 2020; Remuzzi \& Remuzzi, 2020; Vellingiri et al., 2020; Watkins, 2020). Secara global, penyebaran COVID-19 telah melanda 215 negara dengan kasus terkonfirmasi sebanyak 11.424 .843 menyebabkan kematian sebanyak 534.484, dan angka sembuh mencapai 6.473 .335 orang. Indonesia menempati urutan ke-26 kasus positif COVID-19, yaitu sebanyak 63.749 dengan jumlah kasus sembuh 29. 105 dan 
meninggal sebanyak 3.171 orang, berdasarkan data per 5 Juli 2020 (Worldometers, 2020). Kasus COVID-19 pertama kali dilaporkan di Kota Wuhan, Provinsi Hubei, China (Al-Awadhi, Alsaifi, Al-Awadhi, \& Alhammadi, 2020; Cucinotta \& Vanelli, 2020; Heymann \& Shindo, 2020; Phan, 2020; Shu, Ting, Carin, Dzau, \& Wong, 2020; Vellingiri et al., 2020; Wang, Horby, Hayden, \& Gao, 2020). SARS-CoV-2 adalah coronavirus zoonosis yang diduga berasal dari kelelawar. Sejumlah kecil hewan di seluruh dunia termasuk anjing, kucing, harimau dan singa telah terinfeksi secara alami oleh SARS-CoV-2. Dugaan terbesar adanya virus SARS-CoV-2 pada manusia adalah karena penularan yang berasal dari hewan (Newman et al., 2020).

Hampir seluruh aspek kehidupan terpengaruh oleh pandemi COVID-19 (Adam, 2020; Garrett, 2020; Jackson, Weiss, Schwarzenberg, \& Nelson, 2020; Khan, Kazmi, Bashir, \& Siddique, 2020; Mahase, 2020), tak terkucuali dunia pendidikan (Anderson, 2020; Cluver et al., 2020; Daniel, 2020; Gee, 2020; Shu et al., 2020; The World Bank, 2020; van Fleet, 2020). Terkhusus di Indonesia, dunia pendidikan segera merespon dampak pandemi COVID-19. Pemerintah Republik Indonesia, melalui Kementerian Pendidikan dan Kebudayaan memberlakukan kebijakan pembelajaran daring atau online untuk memperlambat penyebaran COVID-19, sekaligus memastikan bahwa aktivitas pembelajaran tetap berlangsung meskipun dalam kondisi pandemi (Wahyono \& Husamah, 2020).Menteri Pendidikan dan Kebudayaan Republik Indonesia mengeluarkan "Surat Edaran Nomor 3 Tahun 2020 tentang Pencegahan COVID-19 pada Satuan Pendidikan“. Sementara itu, Menteri Agama Republik Indonesia pun mengeluarkan "Surat Edaran Nomor 2 Tahun 2020 tentang Penyesuaian Sistem Kerja Pegawai dalam Upaya Pencegahan Penyebaran COVID-19 pada Kementerian Agama". Menindaklanjuti hal tersebut, berbagai perguruan tinggi di lingkungan Kementerian Agama merespon dengan mengeluarkan kebijakan pencegahan penyebaran COVID-19. Rektor UIN Sunan Ampel Surabaya telah mengeluarkan beberapa Surat Edaran terkait hal ini diantaranya Surat Edaran Nomor 400, 406, dan 413 yang dimasing-masing dikeluarkan pada tanggal 18 Maret, 22 Maret, dan 30 Maret 2020. Berdasarkan Surat Edaran Rektor UIN Sunan Ampel Surabaya tersebut, perkuliahan dialihkan ke sistem daring dengan memanfaatkan berbagai platform, termasuk diantaranya adalah media sosial yang ada sampai akhir Semester Genap Tahun Akademik 2019/2020.

Terdapat beberapa jenis pembelajaran daring, yaitu knowledgebase, online support, pelatihan asinkron, pelatihan sinkron, dan pelatihan hybrid/blended. Jenis knowledgebase adalah serangkaian pelajaran yang diterbitkan di situs web dan memiliki instruksi umum pembelajaran yang harus diikuti siswa, tanpa dukungan yang tersedia. Jenis online support adalah versi modifikasi dari knowledgebase dimana dukungan tersedia sehingga terdapat papan diskusi, forum web atau cara komunikasi lain yang tersedia sebagai fitur pendukung beberapa topik. Pelatihan asinkron adalah pelatihan yang tidak dilakukan secara real-time, tetapi para siswa diberikan pelatihan konten secara teratur. Instruktur ditugaskan untuk memberi dukungan melalui email atau platform komunikasi lainnya. Pelatihan sinkron adalah pelatihan yang dilakukan secara real-time dengan instruktur langsung dan moderator opsional. Ada waktu yang telah ditentukan sebelumnya untuk masuk ke lingkungan pendidikan online dan peserta dapat berkomunikasi langsung dengan anggota kelompok lainnya. Pelatihan hybrid adalah kombinasi interaksi online dan tatap muka (Basilaia \& Kvavadze, 2020).

Hampir seluruh institusi pendidikan tinggi di Indonesia melaksanakan perkuliahan secara daring, sebagai alternatif paling logis menyikapi adanya pandemi 
COVID-19. Hal ini sesuai dengan anjuran Menteri Pendidikan dan Kebudayaan agar seluruh perguruan tinggi baik negeri maupun swasta melaksanakan Study from Home (SFH) pada semester genap tahun akademik 2019/2020 dan dapat diperpanjang satu semester berdasarkan Surat Edaran Nomor 302/E.E2/KR/2020 yang dikeluarkan pada 31 Maret 2020. Keputusan bersama Kementerian Pendidikan dan Kebudayaan, Kementerian Agama, Kementerian Kesehatan, dan Kementerian Dalam Negeri yang dikeluarkan pada 15 Juni 2020 memutuskan bahwa tahun ajaran baru 2020/2021 pada daerah di zona kuning, orange dan merah tetap dilaksanakan secara SFH. Melihat hal tersebut, maka pelaksanaan perkuliahan daring yang telah dilakukan pada Semester Genap Tahun Ajaran 2019/2020 perlu untuk dianalisis.

Sejauh ini, publikasi terkait dengan implementasi pembelajaran atau perkuliahan daring di Perguruan Tinggi, masih jarang ditemukan. Apalagi bila kita memfokuskan kepada pembelajaran atau perkuliahan di Fakultas Sains/MIPA, Fakultas Tadris/Keguruan dan Ilmu Pendidikan, atau secara khusus ke Program Studi Biologi atau Program Studi Pendidikan Biologi. Beberapa publikasi yang ada lebih memfokuskan kepada aspek lain, misalnya review implementasi pembelajaran daring yang dilakukan guru (Wahyono \& Husamah, 2020), literasi COVID-19 pada mahasiswa (Fauzi et al., 2020), pandangan guru matematika sekolah menengah terkait dengan pembelajaran daring (Mailizar, Almanthari, Maulina, \& Bruce, 2020), pembelajaran daring di pendidikan matematika (Mulenga \& Marbán, 2020), dan performa siswa kelas 12 (Sintema, 2020). Dengan demikian penelitian dan publikasi ini menjadi sangat penting atau relevan untuk dilakukan.

Oleh karena itu, penelitian ini bertujuan untuk menganalisis proses dan kendala pembelajaran biologi di masa pandemi COVID-19 berdasarkan respon mahasiswa. Penelitian dan publikasi ini memiliki kontribusi sebagai evaluasi dan acuan hal-hal positif, maupun acuan perbaikan pembelajaran pada pelaksanaan perkuliahan daring semester berikutnya. Hasil penelitian ini juga dapat menjadi contoh dan rujukan tentang bagaimana melakukan analisis pembelajaran di masa pandemi pada level perguruan tinggi.

\section{METODE}

Jenis penelitian ini adalah deskriptif kualitatif. Penelitian kualitatif ditujukan untuk memahami fenomena-fenomena sosial dari sudut atau perspektif partisipan dengan tujuan untuk mendeskripsikan dan mengungkapkan. Penelitian deskriptif dilakukan dengan menjelaskan atau menggambarkan variabel yang terjadi pada masal lalu dan sekarang, yang dalam penelitian ini difokuskan pada pembelajaran biologi di masa pandemi COVID-19. Penelitian dilakukan pada Semester Genap Tahun Akademik 2019/2020.

Teknik pengumpulan data dalam penelitian ini menggunakan angket dalam bentuk Google form yang dibagikan kepada para responden. Responden adalah mahasiswa Program Studi Biologi UIN Sunan Ampel Surabaya angakatan 2017, 2018, dan 2019, dengan jumlah total sebanyak 82. Komponen dalam angket terdiri dari identitas responden serta pertanyaan untuk mengetahui proses pelaksanaan pembelajaran daring selama masa pandemi COVID-19 dan kendala yang dihadapi mahasiswa (11 pertanyaan). Selanjutnya, data yang terkumpul dari angket tersebut dikelompokkan dalam tabel, dipersentase, lalu ditampilkan dalam bentuk diagram, dianalisis dan kemudian dideskripsikan. 


\section{HASIL DAN PEMBAHASAN \\ Profil Responden}

Data penelitian ini berupa respon yang diberikan oleh para responden dari angket yang telah disebar melalui Google form. Responden dalam penelitian adalah mahasiswa Program Studi Biologi UIN Sunan Ampel Surabaya, Jawa Timur. Jumlah responden sebanyak 82 mahasiswa yang terdiri dari 33\% angkatan 2019, 40\% angkatan 2018, dan 27\% angkatan 2017.

Responden melakukan perkuliahan daring di rumah masing-masing, sebagaimana kebijakan yang telah dikeluarkan oleh Rektor UIN Sunan Ampel Surabaya. Responden berasal dari berbagai Kabupaten atau Kota di Jawa Timur, yaitu Surabaya 32,4\%, Sidoarjo 28,6\%, Gresik 10,3\%, Lamongan 5,2\%, Jombang dan Bojonegoro masing-masing 3,9\%, Pasuruan, Mojokerto dan Blitar masing-masing 2,6\% sisanya berada di Ponorogo, Bangkalan, Pamekasan, Tuban, dan Kediri masingmasing 1,3\%. Berdasarkan daerah asal, maka dapat dikatakan bahwa secara etnis/suku, responden adalah suku Jawa dan Madura.

\section{Proses Perkuliahan/Pembelajaran}

\section{Kesesuaian Pelaksanaan perkuliahan dengan Jadwal}

Respon mahasiswa terkait dengan pertanyaan kesesuaian pelaksanaan perkuliahan daring dengan jadwal disajikan pada Gambar 1.

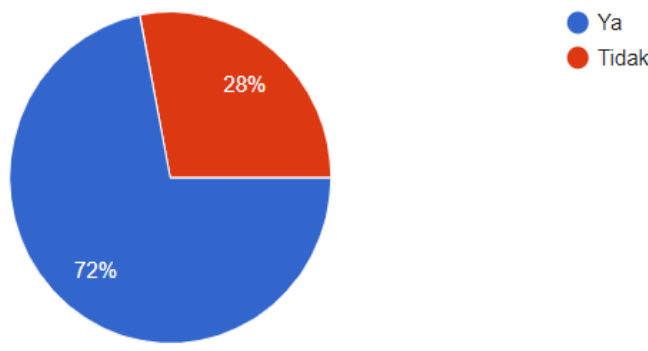

Gambar 1. Data Kesesuaian Pelaksanaan Perkuliahan dengan Jadwal

Dari data yang tersaji pada Gambar 1 tersebut dapat diketahui bahwa pelaksanaan pembelajaran daring telah dilaksanakan sesuai dengan jadwal yang telah dikeluarkan oleh Program studi Biologi ataupun fakultas (yaitu sebesar 72\%). Namun demikian, sebesar $28 \%$ atau 23 orang mengakui bahwa pembelajaran dilakukan di luar jadwal/tidak sesuai jadwal.

\section{Pemahaman materi selama perkualiahan daring}

Gambar 2 menyajikan data respon mahasiswa terkait dengan pemahaman mereka terhadap materi yang diajarkan selama daring.
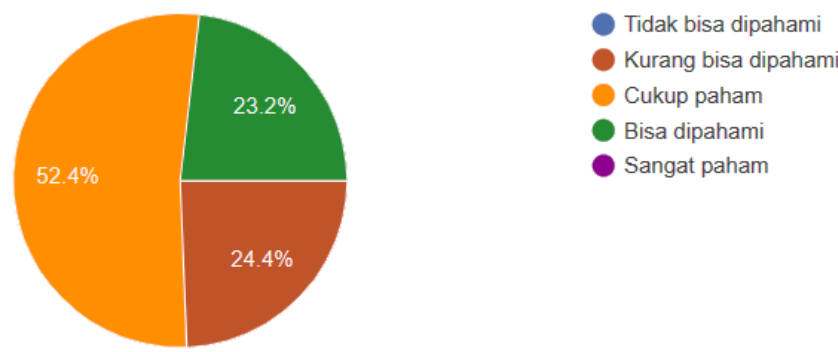

Gambar 2. Pemahaman Materi selama Daring 
Berdasarkan Gambar 2, diketahui bahwa mahasiswa cukup paham terhadap materi yang diberikan selama perkuliahan daring yaitu sebesar 52,4\%. Berikutnya, 23,2\% mengakui materi cukup bisa memahami, sedangkan24,4\% mengatakan kurang paham terhadap materi.

\section{Semangat atau antusiasme dalam perkuliahan daring}

Data semangat atau antusiasme mahasiswa dalam perkuliahan daring disajikan pada Gambar 3.

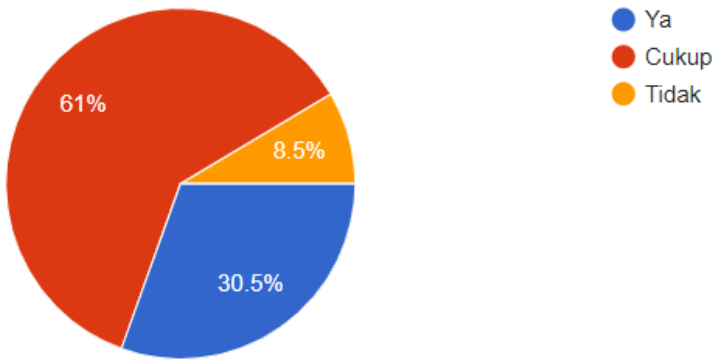

Gambar 3. Semangat/antusiasme dalam perkuliahan daring

Berdasarkan Gambar 3, diketahui bahwa mahasiswa mengaku semangat atau antusias dalam perkuliahan daring (sebesar 30,5\%) sebagian besar mengatkan cukup semangat (sebesar 61\%), dan ada 8,5\% mahasiswa yang mengaku tidak semangat.

\section{Komunikasi antara dosen dengan mahasiswa}

Gambar 4 menunjukkan data respon mahasiswa terhadap aspek komunikasi dosen dengan mahasiswa.

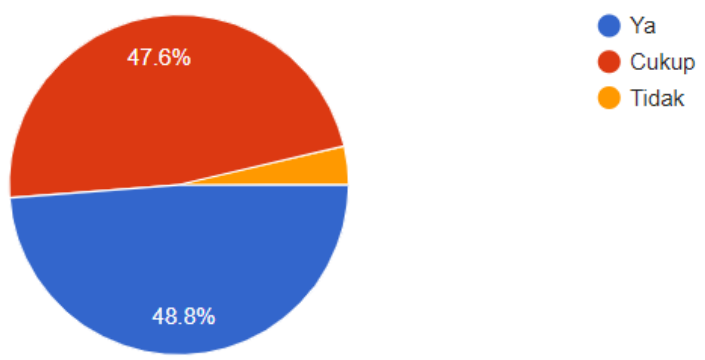

Gambar 4. Komunikasi Dosen dengan Mahasiswa

Gambar 4 menunjukkan bahwa selama perkuliahan daring komunikasi antara dosen dan mahasiswa berjalan baik $(48,6 \%$,), dan cukup 47,6\%.Hanya ada sedikit mahasiswa yang merasa bahwa komunikasi mereka dengan dosen tidak berjalan dengan baik (sebanyak 3,8\%).

\section{Media perkuliahan online yang digunakan.}

Berdasarkan hasil pertanyaan terbuka pada angket tentang media perkuliahan online yang digunakan selama masa pandemi Covid-19 didapatkan hasil bahwa media online yang digunakan diantaranya: (1) Schoology, (2) WhatsApp, (3) Zoom meeting, (4) Google classroom, (5) Kaizala, (6) YouTube, (7) Telegram, (8) PodCast, dan (9) Teamlink. Data tersebut menunjukkan bahwa platform yang digunakan dosen cukup beragam, dimana ditemukan ada sembilan. 


\section{Alat elektronik yang digunakan untuk perkuliahan daring}

Gambar 5 berikut menunjukkan alat elektronik yang biasa digunakan selama perkuliahan daring.

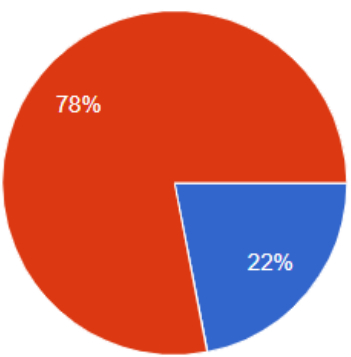

Gambar 5. Alat elektronik selama Perkuliahan Daring

Dari Gambar 5 diketahui bahwa alat elektronik yang digunakan mahasiswa selama perkuliahan daring paling banyak adalah Handphone (sebesar 78\%). Laptop/PC hanya digunakan oleh $22 \%$ mahasiswa.

\section{Terbiasa/Tidak Terbiasa Perkuliahan Daring Selama Masa Pandemi}

Gambar 6 menunjukkan data respon mahasiswa mengenai "terbiasa/tidak" perkuliahan daring selama pandemi.
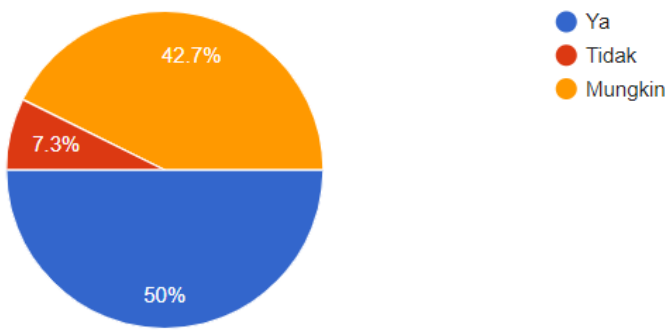

Gambar 6. Terbiasa/tidak terbiasa perkuliahan daring

Berdasarkan Gambar 6 dapat diketahui bahwa bahwa sebagian besar mahasiswa menjawab sudah terbiasa dengan perkuliahan daring (sebesar 50\%). Namun demikian jumlah mahasiswa yang ragu-ragu masih cukup banyak karena yang menjawamungkin ada sebanhyak $42,7 \%$. Mahasiswa yang benar-benar menyatakan tidak terbias adalah sebesar $7,3 \%$.

\section{Metode perkuliahan}

Jawaban mahasiswa mengenai metode perkuliahan yang selama ini digunakan disajikan pada Gambar 7.

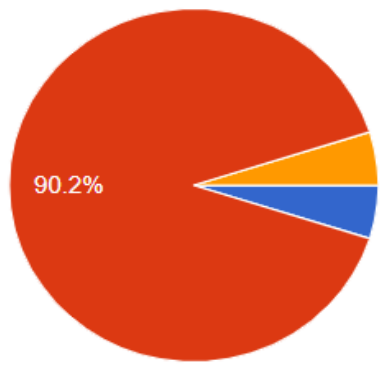


Berdasarkan Gambar 7 diketahui bahwa metode perkuliahan daring yang paling banyak digunakan adalah diskusi online (seeasar 90,2\%) dan sisanya adalahteleconference $(4,9 \%)$ dan lainnya sebanyak 4,9\%. Adapun metode lainnya yang dimaksud adalahberupa gabungan antara dikusi online dan teleconference, diskusi online dan melihat video, diskusi online dan kuis, tugas yang dikumpulkan, serta membuat video presentasi.

\section{Koneksi internet yang digunakan}

Gambar 8 berikut menyajikan respon mahasiswa mengenai fasilitas koneksi internet yang digunakan mahasiswa selama perkulihan daring.

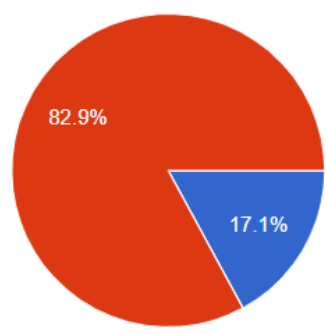

$$
\text { Wata }
$$

Gambar 8. Koneksi Internet yang Digunakan

Gambar 8 menunjukkan bahwa koneksi internet yang paling banyak digunakan mahasiswa dalam perkuliahan daring adalah paket data sebesar $82,9 \%$ dan wifi $17,1 \%$.

\section{Kendala dalam perkuliahan daring}

Beberapa kendala yang ditemui mahasiswa selama perkuliahan daring disajikan pada Gambar 9.

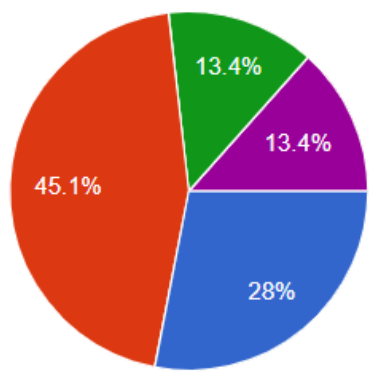

Jaringan internet lemah

Menghabiskan banyak kuota/ kuota

internet habis

Tidak ada alat elektronik

Kondisi kurang kondusif karena

gangguan lingkungan sekitar

Lainnya

Gambar 9. Kendala Perkuliahan Daring

Berdasarkan Gambar 9 diketahui ada beberapa kendala mahasiswa dalam perkuliahan daring, yaitu membutuhkan banyak kuota karenakuota internet habis $(45,1 \%)$, jaringan internet lemah $(28 \%)$, kondisi kurang kondusif karena gangguan lingkungan sekitar (13,4\%), dan lainnya (13,4\%). Kendala lainnya merupakan gabungan antara beberapa kendala tersebut dan kendala tidak mempunyai uang untuk membeli paket data serta kendala dalam pemahaman praktik. 


\section{Sistem Perkuliahan yang Lebih Disuka}

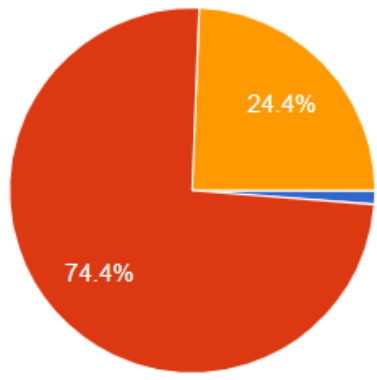

Perkuliahan daring

Perkuliahan tatap muka langsung

Perkuliahan tatap muka langsung

disertai dengan perkuliahan daring

Gambar 10. Sistem Perkuliahan yang Lebih Disukai

Berdasarkan Gambar 10 dapat diketahui bahwa perkuliahan yang lebih disukai mahasiswa adalah adalah perkuliahan tatap muka langsung (sebesar 74,4\%), kombinasi perkuliahan tatap muka langsung disertai perkuliahan daring $(24,4 \%)$, dan perkuliahan daring penuh $(1,2 \%)$.

Adapun data saran dan komentar responden juga telah diperoleh. Secara ringkas,saran dan komentar dari responden, yaitu(1) Terkait jadwal perkuliahan seharusnya tidak melenceng dari jadwal yang telah ditetapkan agar tidak bertabrakan serta tidak melebihi batas waktu yang telah ditentukan; (2)Terkait informasi ujian maupun pengumpulan tugas sebaiknya tidak mendadak tetapi diberi jeda waktu; (3) Seharusnya mahasiswa diberi subsidi kuota; (4) Pemahaman kurang maksimal karena tidak leluasa/tidak bisa bertanya secara langsung; dan (5)Teleconference kurang efektif karena kendala jaringan dan tidak bisa diulang materinya. Sebaiknya penjelasan melalui video atau WAG agar materi bisa diulang-ulang.

Penggunaan internet sudah menjadi hal yang vital dalam penyediaan sumber referensi untuk penelitian dan belajar bagi guru dan peserta didik untuk berbagi dan memperoleh informasi. Perkuliahan atau pembelajaran daringadalah merupakan pembelajaran berbasis teknologi yang mencakup penggunaan internet dan hal-hal penting lainnya seperti menghasilkan bahan untuk belajar, mengajar peserta didik, dan juga mengatur pembelajaran (Arkorful \& Abaidoo, 2015). Di masa pandemi ini, perkuliahan dilakukan dengan jarak jauh dimana mahasiswa dan dosen tetap berada di rumah. Meski berada di rumah, namun perkuliahan tetap dilaksanakan yaitu dengan pelaksanaan perkuliahan daring. Hal ini sesuai dengan pendapat Lopes (2014) dimana keunggulan pembelajaran daring adalah fleksibilitas dan aksesibiltas. Di samping itu, pembelajaran yang dikembangkan di website atau dalam bentuk Learning Management System (LMS) memiliki keuntungan menyediakan konten untuk peserta didik di mana saja. Hal ini memungkinkan akses yang lebih cepat daripada metode pembelajaran konvensional.

Berdasarkan data diketahui bahwa pelaksanaan perkuliahan daring dilakukan sesuai jadwal sebanyak $72 \%$, dan tidak sesuai dengan jadwal sebesar $28 \%$. Tidak sesuainya pelaksanaan perkuliahan dengan jadwal telah banyak dikeluhkan oleh mahasiswa dikarenakan adanya benturan jadwal maupun jadwal yang melebihi batas waktu. Berdasarkan hasil tersebut, maka sebaiknya perkuliahan daring dilakukan sesuai dengan waktu yang telah ditentukan. Kalaupun ada perubahan seharusnya harus ada kesepakatan terlebih dahulu antara mahasiswa dengan dosen. Meskipun demikian, bila ditinjau dari kemudahan akses, perkuliahan daring tetap memiliki keunggulan di mana mahasiswa seharusnya dapat mengakses bahan materi yang 
diberikan oleh dosen kapan saja. Hal ini sebagaimana ditegaskan oleh beberapa artikel penelitian sebelumnya (Husamah \& Rahardjanto, 2018; Lukitasari, Purnamasari, Utami, \& Sukri, 2019; Maryuningsih, Hidayat, Riandi, \& Rustaman, 2019).

Beberapa keuntungan menerapkan perkuliahan daring diantaranya adalah: (1) fleksibiltas, peserta didik memiliki kesempatan untuk memilih waktu dan tempat yang cocok untuknya; (2) dapat meningkatkan pengetahuan karena kemudahan mengakses sejumlah besar informasi; (3) memberikan peluang lebih besar bagi peserta didik dalam forum diskusi online karena dapat menghilangkan hambatan seperti ketakutan untuk berbicara; (4) Daring dinilai hemat biaya karena tidak perlu mengeluarkan uang untuk melakukan perjalanan; (5) dapat membantu mengkompensasi kurangnya staf akademik, termasuk instruktur atau guru serta fasilitator teknisi lab, dan lain-lain; (6) penggunaan daring memungkinkan peserta didik belajar sesuai dengan kecepatannya sendiri, misalnya pada cara asinkron (Arkorful \& Abaidoo, 2015).

Perkuliahan daring dilakukan dengan menggunakan berbagai macam platform, diantaranya Schoology, WhatsApp, Zoom meeting, Google classroom, Kaizala, YouTube, Telegram, Podcast, dan Teamlink. Berdasarkan saran dan komentar dari mahasiswa penggunaan media WhatsApp lebih disukai dikarenakan sedikit menghabiskan kuota. Di samping itu, banyaknya aplikasi yang digunakan untuk perkuliahan daring karena setiap dosen menggunakan aplikasi yang berbeda dapat menyulitkan mahasiswa karena menghabiskan banyak kuota. Sementara WhatsApp merupakan aplikasi yang sudah pasti ada di setiap ponsel mahasiswa. Hal ini didukung dengan data penggunaan alat elektronik, dimana mahasiswa lebih banyak menggunakan Handphone yaitu sebesar 78\% dibandingkan menggunakan Laptop atau PC (22\%).

WhatsApp diakui oleh sebagian besar mahasiswa memiliki keunggulan yaitu mudah digunakan, mudah didapat, dan mudah diunduh. Di samping itu, WhatsApp bersifat sederhana dan dapat menyimpan privasi serta merupakan aplikasi berbiaya rendah dibandingkan dengan jejaring sosial lainnya (Gon \& Rawekar, 2017). Saat ini penggunaan pesan instan WhatsApp untuk meningkatkan interaksi sosial dan berbagi pengetahuan menggunakan telepon pintar meningkat. Peserta didik dalam eksperimennya sering menggunakan WhatsApp dalam kehidupan sehari-hari mereka dan menemukan teknologi yang mudah untuk digunakan. Pesan instan WhatsApp memungkinkan peserta didik untuk menerima pesan dengan cepat. Itu merupakan alat interaktif yang dapat memfasilitasi pertukaran ide dengan cepat (Barhoumi, 2020).

Metode yang digunakan dalam perkuliahan daring di dominasi dengan diskusi daring sebesar 90,2\%, sedangkan sebagian kecil menggunakan teleconference 4,9\%, dan lainnya sebesar 4,9\%. Diskusi daring lebih banyak digunakan dikarenakan bersifat lebih fleksibel dan bisa dibaca berulangkali agar materi lebih bisa dipahami, sedangkan teleconference hanya sedikit digunakan dikarenakan beban kuota yang dihabiskan lebih banyak dan juga jaringan internet yang tidak stabil menyebabkan koneksi sering terputus. Hal ini dapat menghambat pemahaman mahasiswa apabila di tengah perkuliahan terputus maka tidak akan bisa mengulang lagi materi yang telah dibahas. Penggunaan metode diskusi online bisa juga dilengkapi dengan pemberian kuis, pemutaran video, atapun melihat YouTube.

Pilihan aplikasi yang sedikit menghabiskan kuota tentu saja menjadi pertimbangan besar bagi mahasiswa karena lebih banyak mahasiswa melakukan perkuliahan daring dengan menggunakan paket data $(82,9 \%)$ dibandingkan 
menggunakan wifi $(17,1 \%)$. Penggunaan data yang cukup besar saat perkuliahan daring menyebabkan mahasiswa mengeluarkan cukup banyak biaya untuk membeli paket data. Hal ini merupakan kendala utama yang dirasakan oleh mahasiswa, yaitu menghabiskan banyak kuota $(45,1 \%)$. Kendala lainnya adalah jaringan internet lemah $(28 \%)$, dan kondisi kurang kondusif $(13,4 \%)$. Bahkan beberapa saran dari mahasiswa juga berbunyi tentang permintaan subsidi kuota.

Beberapa kekurangan perkulialahan daring diantaranya adalah: menyebabkan peserta didik kurang berinteraksi satu sama lain; (2) klarifikasi, penjelasan, dan interpretasi dalam metode daring mungkin kurang efektif dibandingkan pembelajaran tradisional karena pembelajaran tradisional lebih banyak dan lebih mudah bertatap mula langsung dengan instruktur atau guru; (3) kurang mendukung dalam hal peningkatan keterampilan, daringmungkin dapat meningkatkan pengetahuan dengan sangat baik tetapi efeknya dalam meningkatkan keterampilan sangat kecil; (4) tidak semua disiplin ilmu dapat menggunakan daringsecara efektif dalam pendidikan. Misalnya bidang ilmiah yang membutuhkan pengalaman praktis mungkin lebih sulit untuk dipelajari dalam daring; (5) dapat menyebabkan kemacetan akses atau penggunaan berat (overload) beberapa situs web. Ini dapat menyebabkan hal yang tak terduga baik dalam hal biaya maupun waktu (Arkorful \& Abaidoo, 2015).

Kekurangan yang telah diungkapkan di atas beberapa juga terjadi dalam perkuliahan daring di Prodi Biologi, diantaranya penjelasan yang tidak bisa diterima secara maksimal oleh mahasiswa karena penjelasan secara langsung melalui pembelajaran konvensional dinilai lebih baik dan lebih bisa dipahami oleh mahasiswa dibandingkan penjelasan melalui diskusi daring. Hal ini berdampak pada pemahaman mahasiswa terhadap materi, dimana mahasiswa bisa memahami materi hanya sebesar 23,2\%, yang lebih banyak adalah cukup 52,4\%, dan kurang bisa memahami $24,4 \%$. Di samping itu, materi yang bisa dipahami melalui praktikum juga tidak dapat dilaksankan karena selama masa pandemi COVID-19 perkuliahan dilaksanakan secara daring. Meskipun ada beberapa kendala dalam perkuliahan daring, namun mahasiswa mengaku terbiasa dengan pelaksanaan perkuliahan daring sebanyak 50\%, dan tidak sebesar 7,3\%. Sedangkan antusiasme mahasiswa dalam perkuliahan daring adalah antusias sebesar 30,5\%, cukup $61 \%$, dan kurang antusias $8,5 \%$.

Mahasiswa sudah terbiasa dengan perkuliahan daring. Hal ini sejalan dengan pendapat Farida, Sunarya, Aisyah, dan Helsy (2020) yang menyatakan bahwa mahasiswa sebagai generasi $\mathrm{Z}$, secara kognitif, keterampilan dan sikap tidaklah memiliki kendala yang berarti dalam menempuh pembelajaran daring. Penggunaan teknologi untuk membantu mahasiswa belajar dapat dilaksanakan dengan baik jika mereka didukung oleh faktor-faktor eksternal yang dapat mengatasi hambatan belajar, yaitu ketersediaan jaringan internet yang memadai untuk akses belajar, platform daring dan media pembelajaran yang sesuai dengan konten pembelajaran, serta suasana lingkungan kondusif yang mendukung motivasi dan semangat belajar.

Berdasarkan hasil survei juga diketahui bahwa mahasiswa lebih memilih perkuliahan tatap muka langsung $(74,4 \%)$ dibandingkan dengan perkuliahan daring $(1,2 \%)$, sisanya mahasiswa memilih perkuliahan tatap muka langsung yang disertai dengan perkuliahan daring $(24,4 \%)$. Banyaknya mahasiswa yang memilih perkuliahan tatap muka langsung tentu saja berkaitan dengan banyaknya kekurangan yang dirasakan oleh mahasiswa saat melaksanakan perkuliahan daring, baik yang berkaitan dengan pemahaman, kurangnya kegiatan praktikum, banyak 
biaya yang digunakan untuk membeli paket data, jaringan internet yang kurang stabil maupun kondisi lingkungan belajar yang kurang kondusif.

Berdasarkan beberapa hal yang telah diungkapkan di atas maka sebaiknya perkuliahan daring terus dilakukan evaluasi untuk menjadi bahan perbaikan pada proses perkulaiahn daring berikutnya. Beberapa hal yang bisa menjadi pertimbangan agar proses perkuliahan daring berjalan lebih baik diantaranya adalah: (1) setiap dosen tidak menggunakan banyak aplikasi yang berbeda agar mahasiswa tidak bingung dengan banyaknya aplikasi yang digunakan, (2) memilih aplikasi yang lebih mudah digunakan serta tidak banyak menghabiskan kuota; (3) selalu memantau jalannya diskusi atau perkuliahan daring. Jangan sampai mahasiswa dikusi sendiri karena akan menyebabkan miskonsepsi; (4) memastikan komunikasi tetap berjalan dengan baik; (5) menggunakan metode-metode kreatif agar mahasiswa tidak bosan dan bisa lebih memahami materi yang disampaikan, misalnya membuat video pembelajaran; (6) mengantisipasi kegiatan pratikum yang tidak bisa dilakukan di kampus, maka sebaiknya dosen membuat rancangan praktikum sedemikian rupa yang bisa dilaksanakan mahasiswa di rumah.

\section{KESIMPULAN}

Pelaksanaan perkuliahan daring di Prodi Biologi UIN Sunan Ampel Surabaya pada Semester Genap Tahun Ajaran 2019-2020 berjalan baik. Hal ini didasarkan pada persentase respon mahasiswa pada sepuluh pertanyaan yang diberikan.

\section{SARAN}

Beberapa kendala utama dirasakan mahasiswa pada perkuliahan daring, yaitu menghabiskan banyak kuota, dan jaringan internet lemah. Proses perkuliahan masih perlu untuk terus dioptimalkan, oleh karena itu perlu dilakukan evaluasi demi perbaikan pada proses perkuliahan daring pada periode berikutnya. Kondisi pandemi COVID-19 menyebabkan perubahan signifikan dalam dunia pendidikan, dimana proses pembelajaran harus dilaksanakan secara daring. Kondisi seperti ini hampir belum pernah terjadi sebelumnya. Oleh karena itu, penelitian mengenai proses pembelajaran daring perlu dilakukan agar terus mengalami peningkatan dalam pelaksanannya karena sejauh ini masih banyak proses pembelajaran daring yang mengalami banyak kendala.

\section{UCAPAN TERIMA KASIH}

Penelitian ini tidak menerima hibah khusus dari agensi pendanaan mana pun di sektor publik, komersial, atau nirlaba.

\section{DAFTAR PUSTAKA}

Adam, D. (2020). Modelling the pandemic: The simulations driving the world's response to COVID-19. Nature, 580(April), 316-318. https:/ / doi.org/10.1038/d41586-020-01003-6

Al-Awadhi, A. M., Alsaifi, K., Al-Awadhi, A., \& Alhammadi, S. (2020). Death and contagious infectious diseases: Impact of the COVID-19 virus on stock market returns. Journal of Behavioral and Experimental Finance, 27, 100326. https:/ / doi.org/10.1016/j.jbef.2020.100326

Anderson, J. (2020, March 4). Should schools close when coronavirus cases are still rare? Quartz. Retrieved from https://qz.com/1810224/does-closing-schoolsprotect-kids-and-us-from-coronavirus/ 
Arkorful, V., \& Abaidoo, N. (2015). The role of e-learning, advantages and disadvantages of its adoption in higher education. International Journal of Instructional Technology and Distance Learning, 12(1), 29-42. Retrieved from https://www.ijern.com/journal/2014/December-2014/34.pdf

Barhoumi, C. (2020). The Effectiveness of WhatsApp Mobile Learning Activities Guided by Activty Theory on Students' Knowldege Management. Contemporary Educational Technology, 6(3), 221-238. https://doi.org/10.30935/cedtech/6151

Basilaia, G., \& Kvavadze, D. (2020). Transition to Online Education in Schools during a SARS-CoV-2 Coronavirus (COVID-19) Pandemic in Georgia. Pedagogical Research, 5(4), em0060. https://doi.org/10.29333/pr/7937

Cluver, L., Lachman, J. M., Sherr, L., Wessels, I., Krug, E., Rakotomalala, S., ... McDonald, K. (2020). Parenting in a time of COVID-19. The Lancet, 2019(20), 30736. https:/ / doi.org/10.1016/s0140-6736(20)30736-4

Cucinotta, D., \& Vanelli, M. (2020). WHO declares COVID-19 a pandemic. Acta BioMedica: Atenei Parmensis, 91(1), 157-160. https://doi.org/10.23750/abm.v91i1.9397

Daniel, S. J. (2020). Education and the COVID-19 pandemic. Prospects, 2020, 1-6. https:// doi.org/10.1007/s11125-020-09464-3

Farida, I., Sunarya, R. R., Aisyah, R., \& Helsy, I. (2020). Pembelajaran Kimia Sistem Daring di Masa Pandemi Covid-19 Bagi Generasi Z. In KTI UIN Sunan Gunung Djati. Retrieved from http://digilib.uinsgd.ac.id/30638/1/KTI -Ida Farida \%2Cdkk- P Kimia.pdf

Fauzi, A., Husamah, H., Miharja, F. J., Fatmawati, D., Permana, T. I., \& Hudha, A. M. (2020). Exploring COVID-19 literacy level among biology teacher candidates. Eurasia Journal of Mathematics, Science and Technology Education, 16(7), em1864. https://doi.org/10.29333/EJMSTE/8270

Garrett, L. (2020). COVID-19: The medium is the message. The Lancet, 395(10228), 942943. https://doi.org/10.1016/S0140-6736(20)30600-0

Gee, G. (2020). COVID-19: Impact on student predictions. Retrieved from www.civitaslearning.com

Gon, S., \& Rawekar, A. (2017). Effectivity of E-Learning through Whatsapp as a Teaching Learning Tool. MVP Journal of Medical Sciences, 4(1), 19-25. https://doi.org/10.18311/mvpjms/2017/v4i1/8454

Heymann, D. L., \& Shindo, N. (2020). COVID-19: what is next for public health? The Lancet, 395(10224), 542-545. https:// doi.org/10.1016/S0140-6736(20)30374-3

Hsu, L. Y., Chia, P. Y., \& Vasoo, S. (2020). A midpoint perspective on the COVID-19 pandemic. Singapore Medical Journal, 0(0), 1-10. https://doi.org/10.11622/smedj.2020036

Husamah, H., \& Rahardjanto, A. (2018). OIDDE-PjBL learning model: Problemsolving skillsand product creativity for study of biology prospective teachers. The 3rd Progressive and Fun Education International Seminar ISBN:, 41-51. Surabaya: ALPTK PTM.

Jackson, J. K., Weiss, M. A., Schwarzenberg, A. B., \& Nelson, R. M. (2020). Global economic effects of COVID-19. Retrieved from https://fas.org/sgp/crs/row/R46270.pdf

Khan, M., Kazmi, S., Bashir, A., \& Siddique, N. (2020). COVID-19 infection: Origin, transmission, and characteristics of human coronaviruses. Journal of Advanced Research, 24, 91-98. https://doi.org/10.1016/j.jare.2020.03.005

Lloyd-Sherlock, P. G., Kalache, A., McKee, M., Derbyshire, J., Geffen, L., Casas, F. G.- 
O., \& Gutierrez, L. M. (2020). WHO must prioritise the needs of older people in its response to the covid-19 pandemic. BMJ (Clinical Research Ed.), 368(m1164), 1. https://doi.org/10.1136/bmj.m1164

Lopes, A. P. (2014). Learning management Systems in higher education. Proceedings of EDULEARN14 Conference, (July), 5360-5365. Retrieved from file:/ / / C:/Users/User/Downloads/naskah bu ita/47139697.pdf

Lukitasari, M., Purnamasari, I., Utami, S., \& Sukri, A. (2019). Blended-Problem-Based Learning: How its impact on students' critical thinking skills? JPBI (Jurnal Pendidikan Biologi Indonesia), 5(3), 425-434. https://doi.org/10.22219/jpbi.v5i3.10048

Mahase, E. (2020). Covid-19: WHO declares pandemic because of "alarming levels" of spread, severity, and inaction. BMJ (Clinical Research Ed.), 368(m1036), 1. https://doi.org/10.1136/bmj.m1036

Mailizar, Almanthari, A., Maulina, S., \& Bruce, S. (2020). Secondary school mathematics teachers' views on e-learning implementation barriers during the COVID-19 pandemic: The case of Indonesia. Eurasia Journal of Mathematics, Science and Technology Education, 16(7), em1860. https:/ / doi.org/10.29333/EJMSTE/8240

Maryuningsih, Y., Hidayat, T., Riandi, R., \& Rustaman, N. (2019). Developing Gen21cs on smartphone to cultivate the 21st-century skills on biology teacher candidates. JPBI (Jurnal Pendidikan Biologi Indonesia), 5(3), 415-424. https://doi.org/10.22219/jpbi.v5i3.9714

Mulenga, E. M., \& Marbán, J. M. (2020). Prospective teachers' online learning Mathematics activities in the age of COVID-19: A cluster analysis approach. EURASIA Journal of Mathematics, Science and Technology Education, 16(9), em1872. https://doi.org/10.29333/ejmste/8345

Newman, A., Smith, D., Ghai, R. R., Wallace, R. M., Torchetti, M. K., Loiacono, C., ... Barton Behravesh, C. (2020). First Reported Cases of SARS-CoV-2 Infection in Companion Animals - New York, March-April 2020. MMWR. Morbidity and Mortality Weekly Report, 69(23), 710-713. https://doi.org/10.15585/mmwr.mm6923e3

Phan, T. (2020). Genetic diversity and evolution of SARS-CoV-2. Infection, Genetics and Evolution, 81(February), 104260. https:// doi.org/10.1016/j.meegid.2020.104260

Remuzzi, A., \& Remuzzi, G. (2020). COVID-19 and Italy: What next? The Lancet, 2, 1013. https://doi.org/10.1016/S0140-6736(20)30627-9

Shu, D., Ting, W., Carin, L., Dzau, V., \& Wong, T. Y. (2020). Digital technology and COVID-19. Nature Medicine. https:/ / doi.org/10.1038/s41591-020-0824-5

Sintema, E. J. (2020). Effect of COVID-19 on the Performance of Grade 12 Students: Implications for STEM Education. Eurasia Journal of Mathematics, Science and Technology Education, 16(7), em1851. https:/ / doi.org/10.29333/ejmste/7893

The World Bank. (2020). Remote learning, EdTech \& COVID-19. Retrieved April 5, 2020, from BRIEF website: https://www.worldbank.org/en/topic/edutech/brief/edtech-covid-19

van Fleet, J. (2020). Education in the time of COVID-19. Retrieved from https://www.globalpartnership.org/blog/education-time-covid-19

Vellingiri, B., Jayaramayya, K., Iyer, M., Narayanasamy, A., Govindasamy, V., Giridharan, B., ... Subramaniam, M. D. (2020). COVID-19: A promising cure for the global panic. Science of The Total Environment, 725, 138277. https:/ / doi.org/10.1016/j.scitotenv.2020.138277

Wahyono, P., \& Husamah, H. (2020). Guru profesional di masa pandemi COVID-19: 
Review implementasi, tantangan, dan solusi pembelajaran daring. Jurnal Pendidikan Profesi Guru, 1(1). https:/ / doi.org/10.22219/jppg.v1i1.12462

Wang, C., Horby, P. W., Hayden, F. G., \& Gao, G. F. (2020). A novel coronavirus outbreak of global health concern. The Lancet, 395(10223), 470-473. https:/ / doi.org/10.1016/S0140-6736(20)30185-9

Watkins, J. (2020). Preventing a covid-19 pandemic. The BMJ, 368(February), 1-2. https://doi.org/10.1136/bmj.m810

Worldometers. (2020). COVID-19 coronavirus pandemic (Last updated: July 05, 2020, 14:23 GMT). Retrieved July 5, 2020, from Coronavirus website: https://www.worldometers.info/coronavirus/ 